\title{
KAPTAN PAŞA ve HUKUKÎ STATÜSÜ
}

\author{
Dr. Aybars PAMIR*
}

\section{GiRiș}

Makalemizle, Osmanlı Devleti'nde oldukça geç gelişen ve zamanla devlet örgütünün en önemli kurumlarından biri haline gelen Kaptan Paşalığın hukukî statüsünü devletin kuruluşundan yıkılışına kadarki süreçte incelemek amaçlanmıştır. Aslında, daha ziyade bir kara devleti olarak temelleri atılan Osmanlı Devleti, kısa sürede genişleyerek önemli bazı kıyı ve adalara da hakim olmuş, bu durum denizciliğin zamanla önem kazanması sonucunu doğurmuştur. İşte "Kaptan Paşalık" bu gelişmeler sonucunda oluşan bir devlet kurumudur.

Kaptan Paşalık devletin diğer kurumları gibi zaman içinde kendi gelenek ve kurallarını oluşturmuştur. Tarihin en büyük devletlerinden birini kurmuş olan Osmanlılar'ın sadece bir kara devleti olmayıp, denizciliğe de gereken önemi vermeleri Kaptan Paşahk makamına atfettikleri yüksek değerle açılanabilir.

\section{GENEL OLARAK}

Osmanlı merkez örgütünün yöneticilerinden biri olan "Kaptan Paşa (Kaptan-ı Derya)" önemli denizaşırı eyaletleri ve adaları yönetmek, ayrıca donanmanın her an güçlü tutulmasını sağlamakla görevliydi.' O, aynı

\footnotetext{
* Ankara Üniversitesi Hukuk Fạültesi, Hukuk Tarihi Anabilim Dalı Araştırma Görevlisi.

I ÜÇOK, Coşkun - MUMCU, Ahmet - BOZKURT, Gülnihal; Türk Hukuk Tarihi, Ankara, 1996, s.208.
} 
zamanda Osmanlı Bahriyesi'nin en büyük amiri ve donanmanın başkomutaniyds.?

"Kaptan Paşa (Kaptan-1 Derya)" unvanı Italyanca "Capitano" kelimesinden Türkçe'ye geçmiştir. Kelime menşey itibarıyla Lâtince "Capitaneus" veya "Capitanus" kelimelerinden gelmekte olup, XVI. yüzyıldan itibaren Türkler'de "Derya Beyi" unvanının yerine kullanılmaya başlanmıştır. Bu unvanın alınmasında, zamanın denizci kavimleri Venedik ve Cenevizliler'den etkilenildiği doğrudur; ancak bu etkileşim, sözü edilen devletlerdeki teşkilâtın bire bir alınması sonucunu getirmemiştir. ${ }^{3}$

Yukarıda söz edildiği gibi, Osmanhı Devleti'nde XVI. yüzyıldan önce Kaptan Paşalık görevini "Derya Beyi" unvanıyla yürüten görevliler mevcuttu. Yıldırım Beyazıt zamanında Gelibolu Tersanesi'nin kurulmasımı izleyen tarihlerde Akdeniz (Çanakkale) Boğazı'nın korunması ve Anadolu ile Rumeli arasında irtibat sağlanması gibi görevleri yürütmek üzere derya beyleri görev yapmışlardır. Zamanla devletin genişlemesine paralel olarak donanma ile ilgili işlerin çoğalması üzerine, bu makama daha yüksek rütbede ve yetkideki kişilerin atanması gerekmiştir. ${ }^{4}$ Böylece Kaptan Paşalık, denizciliğin gelişmesiyle ortaya çıkan ve oldukça geç gelişen bir yiiksek memurluk olarak Osmanlı Devlet Teşkilâtı içindeki yerini almıştır.

\section{OSMANLI DENIZCILIĞININ GELIŞMESI ve KAPTAN PAŞALIK MAKAMININ KURULUŞU}

Daha çok bir kara devleti görünümünde temeli atılan Osmanlı Devleti Marmara Denizi ile yakınlığı, Rumeli kıyısında bazı yerlerin işgali ve oralara yerleşilmesi sonucu denize dönük bir politika izlemeye başlamıştır. Zaman içinde Ege Denizi, Karadeniz kıyıları ve Akdeniz sahillerindeki çeşitli bölgeler de Osmanlı topraklarına katılınca donanmaya ve deniz gücüne duyulan ihtiyaç artmıştır.

Henüz devletin ilk zamanlarında Karamürsel'de ve Karesi Beyliği'nin Osmanlı topraklarına katılmasindan sonra da Aydıncik'ta birer tersane kurulmuş, onları İzmit'in Bizans'tan alınmasından sonra burada kurulan tersane izlemiştir. Osmanlılar'ın Rumeli'ye yerleşmesinden sonra bölgenin elde tutulması ve gerektiğinde süratle asker sevkedilebilmesi, özellikle de Boğazlar ve Marmara sahillerinin Venedikliler'den korunabilmesi için Gelibolu'da da bir tersane oluşturulmuştur. Bu gelişmelerle birlikte Osmanlı donanma faaliyetlerinin XIV. yüzyılın son yarısından itibaren bir gelişme

2 UZUNÇARŞILı, İsmail Hakkı; Osmanlı Devleti'nin Merkez ve Bahriye Teşkilâtı, Ankara, 1988 , s.414.

3 PARMAKSIZOĞLU, İsmet; Kaptan Paşa, İslâm Ansiklopedisi, C.: VI, İstanbul. 1967, S.206.

4 PARMAKSIZOĞLU; a.g.m., s.207.

5 MUMCU, Ahmet; Divan-ı Hümayun, Ankara, 1986, s.54. 
sürecine girdiği görülmektedir. Ancak, devletin deniz gücü henüz Venedik, Ceneviz gibi denizcilikte ileri gitmiş bazı devletlerin fillolarıyla rekabet edebilecek derecede değildir. ${ }^{6}$

Yıldırım Beyazıt Batı Anadolu'daki Saruhan, Aydın ve Menteşe Beylikleri'ni ortadan kaldırıp ülkesinin sınırlarını Ege Denizi'ne kadar genişlettikten sonra, bu denizde ilk donanma faaliyetlerini başlatmıştır.? Osmanlı denizciliğinde $X V$. yüzyılın ilk yarısından itibaren büyük bir canlanma görülmektedir. Nitekim, Çelebi Mehmet zamanında Venedik Donanması'na önemli zararlar verilmiş; ; II.Murat döneminde ise Trabzon Rum İmparatorluğu vergiye bağlanmıştır.'

Fatih Sultan Mehmet dönemi Osmanlı denizciliğinde bir dönüm noktası sayılır. Geçmiş dönemlerde denizcilikte ileri gitmiş çeşitli devletlerin tarihleriyle ilgili eserleri inceleyerek bu devletlerin donanmalarıyla ilgili fikirler edinen Fatih, özellikle Venedikliler'e karşı kuvvetli bir donanma gücünün meydana getirilebilmesi için çalışmalarda bulunmuştur. İstanbul'un fethinden sonra tersaneyi önce Kadırga Limanı'na, daha sonra da Haliç'e naklettiren Fatih, kurdurduğu gemi inşaat tezgâhları sayesinde yeni donanma inşasına girişmiştir. Boğaz etrafındaki ve Ege Denizi’ndeki kimi adaları zaptederek sahillerin güvenliğini de sağlayan bu Padişah'ın denizcilik alanındaki girişimleri sonucunda, Osmanlı Donanması akın donanması olmaktan çıkıp bir savaş donanması halini almaya başlamıştır. ${ }^{10}$

Osmanlı Devleti'nin Yakındoğu ve Doğu Akdeniz'deki yükselişi ve Türk denizciliğinin evrensel bir gelişme göstermesi ise II.Beyazıt Dönemi (1481-1512)'ne rastgelmektedir. Bu Padişah açık denizlere hakim bir deniz gücüne sahip olunmadığı sürece Venedikliler'le başedilemeyeceğini, dolayısıyla devletin geleceği için Doğu Akdeniz'de deniz hakimiyetinin kurulmasının çok önemli olduğunu anlamıştır. II.Beyazıt bu amaçla Osmanlı Donanması'nı yeni bir tarzda teşkilâtlandırma gereğini duymuş; 1495'de devrin en büyük denizcisi Kemal Reis'i devlet hizmetine alarak Türk denizcilik tarihinde "Büyük Türk Donanma Kaptanları" çağını açmıştır."

II.Beyazıt'tan sonra padişah olan Yavuz Sultan Selim döneminde gelişimini sürdüren Osmanlı denizciliği, Kanunî Sultan Süleyman

" GENCER, Ali İhsan; Bahriyede Yapılan Islahat Hareketleri ve Bahriye Nezaretinin Kuruluşu, Ankara, 2001, s.6,7

7 Yıldınm Beyazıt dönemindeki sözü edilen gelişmelerle ilgili aynntılı bilgi için bkz.; UZUNÇARŞILI, İsmail Hakkı; Osmanlı Tarihi, C.: I, Ankara, 1982, s.260 vd.

8 UZUNÇARŞILI; Osmanlı Tarihi, C.: I, s.353 vd.

9 GENCER; .a.g.e., s.8.

"1 YÜCEL, Yaşar - SEVİM, Ali; Türkiye Tarihi, C.: Il, Ankara, 1990, s.148.

${ }^{11}$ GENCER; a.g.e., s.9,10. - II.Beyazıt döneminde denizcilik alanında kaydedilen gelişmelerle ilgili ayrıntılı bilgi için bkz.; SAKAOĞLU, Necdet; Bu Mülkün Sultanları, İstanbul, 1999, s.126. 
döneminde en parlak devrini yaşamıștır. Bu Padişah zamanında Osmanlı Devleti denizcilikte Avrupa'nın denizci devletlerinden daha üstün bir konuma gelmiş, sonuçta Karadeniz ve Kızıldeniz'den sonra Akdeniz de bir Türk gölü haline getirilmiştir. ${ }^{12}$

İşte, sözü edilen gelişmelerin bir sonucu olarak XVI. yüzyılın ortalarından itibaren bahriye teşkilâtının başında yer alan kişi Kaptan Paşa (Kaptan-1 Derya) adıyla anılmaya başlanmış ve devlet örgütünün en önemli yöneticilerinden biri olmuştur.

\section{KAPTAN PAŞA'NIN ATANMASI}

Kaptan Paşa'nın mutlaka denizcilikten yetişmiş olması gerekmemekteydi. Eyalet valilerinden veya kubbealtı vezirlerinden herhangi biri de kaptan paşalığa atanabilirdi. Ancak bu usulden çoğu kez zarar görülmüş ve türlü zamanlarda kaptan paşalığa devamlı surette denizcilikten gelen kişilerin atanması yolunda kanunlar çıkarılmıştır. Ancak kaptan paşalığa denizcilikten gelen birinin tayininde de kesin bir usulün saptanamadığı göze çarpmaktadır. Bazen Kaptan Paşa'dan sonra en büyük donanma komutanı olan "Kapudâne-i Hümayun" denilen amiral, bazen Kaptan Paşa Eyaleti'nde bulunan sancakbeylerinden biri, bazen de tersane reisi ya da tersane kethüdası bu makama getirilebilmiştir.

"Kaptan Paşalık" makamına atama yapıldığı zaman, atanan kişinin rütbesine; yani beylerbeyi veya vezir olmasına göre belirli sayılarda top atılması kanundu. ${ }^{13}$

Kaptan Paşa olarak tayin edilecek kişi Bâb-1 âlî'ye davet olunur, kendisine Vezir-i azam huzurunda kaptan paşalığa tayin edildiğine dair ferman okunurdu. Ardından kürk giydirilen yeni Kaptan Paşa alayla birlikte Tersane' ye götürülür, orada da bir tören yapılırd..$^{14}$

${ }^{12}$ Kanunî Sultan Süleyman döneminde Barbaros Hayrettin Paşa'nın kazandığı Preveze Zaferi (1539) ile Akdeniz'in Türk egemenliğine geçmesi süreci tamamlanmış sayılır. Bu konuda ayrıntılı bilgi için bkz; YÜCEL, Yaşar - SEVIM, Ali; Klâsik Dönemin Ü ̧̧ Hükümdarı ; Fatih - Yavuz- Kanunî, Ankara, 1991, s.188 vd. - AFETINAN, A.; Pirî Reis'in Hayatı ve Eserleri, Ankara, 1992, s.4-6.- SAKAOĞLU; a.g.e., s.152.

${ }^{13}$ UZUNÇARŞILI; Osmanlı Devleti'nin Merkez ve Bahriye Teşkilâtı, s.414,415.

${ }^{14} 1821$ yılında Nasuhzâde adıyla da bilinen Kapudâne-i Hümayun Ali Bey'e vezirlikle birlikte Kaptan Paşalık ve Cezayir Eyaleti verilirken düzenlenen tören konuyla ilgili güzel bir örnek teşkil etmektedjr:

Ali Bey Bâb-ı âlî'ye davet edilmiş, Hazine Odası'nda otururken vezirlik takımı hazırlanmış ve kendisi Sadrazam'ca kabul olunmuştur. Sadrazam. Ali Bey’i karşılamak üzere ayağa kalktığı sırada Ali Bey etek öpmüş, ardından Sadrazam'ın oturmasını mütcakip o da oturmuştur. Birlikte otururlarken kahve ve çubuk içiłmiş, bir süre özel sohbet edilmiş, o sırada şerbet, buhur tütsüsü ve gülsuyu getirilerek ikram edilmiştir. Bir süre sonra Bâb-1 âlî ricâli Sadrazam'ın huzuruna girip yerlerine oturmuşlar, teşrifatçının 
Osmanlı Devleti'nde, devletin diğer yüksek rütbeli memurları gibi Kaptan Paşa'nın atanmasında da büyük ve gösterişli törenlerin düzenlenmesi birer Kamu Hukuku geleneği sayılmış ve yüzyıllar boyu sürdürülmüştür.

\section{KAPTAN PAŞA'NIN GÖREV ve SORUMLULUKLARI}

Yukarıda anlatılan gelişim çerçevesinde, zamanla devletin vazgeçilmez kurumlarından biri haline gelen ve kökleşen "Kaptan Paşalık" makamının önemli görev ve sorumlulukları bulunmaktaydı. Bu görev ve sorumluluklar yakından incelendiğinde, Kaptan Paşa'nın hem bir idareci, hem de bir komutan olarak devlet teşkilâtı içinde çok önemli bir yeri işgal ettiği kolayca anlaşılabilmektedir.

\section{A. Divan-ı Hümayun'un Bir Üyesi Olarak Çalışmak}

Kaptan Paşa'nın en önemli görevi Divan-1 Hümayun toplantılarına katılarak denizcilikle ilgili sorunları çözüme ulaştırmaktı. Kaptan Paşa Divan-ı Hümayun'un doğal bir üyesiydi. XVII. yüzyıl başlarında Osmanlı merkez örgütünü yerinde görüp inceleyen ünlü tarihçi Baudier, Kaptan Paşa'nın Divan-1 Hümayun'a katıldığını, eğer rütbesi vezir değilse bütün paşaların en arkasında yer aldığını; eğer rütbesi vezir ise Vezir-i azam'a

işareti ile Ali Bey ayağa kalkmış ve vezirlik fermanı Reisülküttap Efendi tarafından okunduktan sonra kendisine vezirlere mahsus serâsere kaplı samur kürk giydirilmiştir. Ali Bey kürkü giydikten sonra Sadrazam'in eteğini öpmüş ve O'nun kendisine salonun ortasına kadar eşlik etmesini müteakip Bâb-ı âlî ricâli tarafından aşağı divanhânenin ortasına kadar götürülmüştür. Aşağıdaki binek taşında ata bindirilen Vezir Ali Paşa, Çavuşbaşı ve maiyeti tarafından alayla birlikte Kireç İskelesi'ne getirilmiş, oradan da kendisi filika ve kayıklarla Tersane'ye geçmiştir. Tersane iskelesine çıkan Ali Paşa'yı orada kanun gereği Tersane Emini ile birlikte Tersane Kethüdası birlikte karşılamışlardır.

Tersane'ye geldikten sonra doğruca, Tersane'nin Büyük Köşkü'ne geçen Kaptan Paşa, kahve içildikten sonra Çavuşbaşı'ya ve icabeden diğer kişilere hil'ât giydirmiş, ardından da Tersane ricâlinin tebriklerini kabul etmek üzere Divanhane'ye geçmiştir. Burada Tersane Şeyhi'nin dua okumasını müteakip Kaptan Paşa'ya sincap kürkü giydirilmiş, ardindan da mehter marşı eşliğinde kutlama merasimine geçilmiştir.

Ali Paşa, tayininin üçüncü gününde teşekkür olarak Bâb-1 âlî’ye gidip Sadrazam'ı ziyaret etmiştir. Burada Bâb-1 âlî ricâli kendisini karşılamış ve önüne düşerek kendisini Sadrazam'ın huzuruna götürmüş̧ür. Kaptan Paşa oradan ayrilırken Sadrazam kendisine odanın ortasına kadar eşlik etmiş, o da binck taşında Sadrazam tarafından kendisine hediye edilen atına binerken teşekkür anlamında atın yularını öpmüş ve doğruca Şeyhülislâm'ı ziyarete gitmiştir.

Kaptan Paşa'nın teşekkür ziyaretlerinden altı gün sonra Mir-i alem tarafından tuğları, nişancı tarafından da vezirlik diviti Tersane'ye götürülmüştür. (UZUNÇARŞILI; Osmanlı Devleti'nin Merkez ve Bahriye Teşkilâtı, s.418, 419). 
daha yakın bir yerde oturduğunu belirtmiştir. ${ }^{15}$ XVII. yüzyılın ikinci yarısında yazılan Tevkiî Abdurrahman Paşa Kanunnamesi'nde ise, Kaptan Paşa'nın ancak vezir ise; o da arz günlerinde Divan-1 Hümayun'a katılabileceği ifade edilmiştir. Son dönemlerdeki araştırmalarda da Kaptan Paşa'nın ancak "vezir" ise Divan-ı Hümayun üyesi sayılabileceği ortaya konmuştur. Şu durumda Baudier' in "Kaptan Paşa vezir değilse de Divan-1 Hümayun'a katılır, ancak en arkada yer alır" ifadesi șöyle yorumlanabilir: Vezir rütbesinde olmayan yöneticiler Divan-1 Hümayun üyesi sayılmazlar. Bu durumda Kaptan Paşa vezir rütbesinde değilse, sadece kendisinden bilgi alınmak üzere oraya çağrılmış olabilir. ${ }^{16}$ Yoksa, kendisinin Divan-1 Hümayun'un doğal üyesi olabilmesi için mutlaka vezir rütbesinde olması gerekir. ${ }^{17}$

İşte, Kaptan Paşa vezir rütbesinde ise, arz günlerinde Divan-1 Hümayun'a gelip derecesine göre diğer vezirlerin yanında otururdu. Denizcilik işleriyle ilgili olup Divan-1 Hümayun'a gelen davalar kendisine havale edilir, Kaptan Paşa bu davalar için şahsına ayrılan yerde oturur ve gereken kararları verirdi. ${ }^{18}$

Divan-1 Hümayun'da önceleri üzengi ağalarıyla müşterek bir sofraya oturan Kaptan paşalar, zamanla itibarları çoğalınca müstakil bir sofra sahibi de olmuşlardır. ${ }^{19}$

Kaptan Paşa'nın Divan-ı Hümayun'a katılabilmesi açısından bir özelliği daha dikkat çekmektedir: O, her yıl Donanma ile uzun bir süre için denizlere açılır ve merkezden uzaklaşırdı. Denizlerde olduğu sürece Divan-1 Hümayun toplantılarına katılabilmesi de elbette mümkün olamazdı. Divan-1 Hümayun'da onu temsil edecek bir görevlinin bulunup bulunmadı $\breve{g}_{1}$ konusunda elimizde bilgi bulunmamaktadır. Ancak bu durumda, Kaptan Paşa İstanbul'da değilken devletin çok önemli işlerinden sayılan denizcilik

${ }^{15}$ BAUDIER, Michel; Türkler'in Padişahı, Büyük Senyörün Sarayı ile Saray Erkânına Ait Genel Tarih, (1625 ?), Türk Tarih Kurumu Kitaplığındaki Basılmamış Çeviri, s.102'den nakleden; MUMCU; a.g.e., s.54.

${ }^{16}$ MUMCU, a.g.e., s.54,55.

${ }^{17}$ Aslına bakılırsa, denizcilik alanındaki gelişime paralel olarak Kaptan Paşalara zaman içinde vezirlik payesinin verilmesi zorunluluk halini almıştır. Şöyle ki; Kaptan Paşalar ilk zamanlarda beylerbeyi rütbesinde ve teşrifat derecesi itibarıyla da Budin Eyaleti'nden sonra gelmekte idiler. Zamanla teşrifattaki dereceleri, deniz zaferlerinin bir sonucu olarak Anadolu Beylerbeyliği'nden sonra gelmeye başlamıştır. Ancak bir süre sonra bu da kâfi gelmeyerck kendilerine vezirlik rïtbesinin verilmesi zorunlu hale gelmiştir. Böylece XVIl. yüzyılın ortalarından itibaren Kaptan Paşalara vezirlik ya bu makama atanma sırasında, ya da atanmadan pek kısa bir zaman sonra verilmeye başlanmıştır. Bu suretle vczirlik Kaptan Paşalığın esas rütbesi olmuştur. (PARMAKSIZOĞLU; a.g.m., s.208).

${ }^{18}$ MUMCU; a.g.e., s.54,55 - UZUNÇARŞILI; Osmanlı Devleti'nin Merkez ve Bahriye Teşkilâtı, s.417.

${ }^{39}$ PARMAKSIZOĞLU; a.g.m., s.208. 
konularının Divan-ı Hümayun'da görüşülmüyor olduğunun da kabul edilmesi gerekmektedir. ${ }^{20}$ Kaptan Paşa'nın bu yönü itibariyla Rumeli Beylerbeyi ile bir benzerlik gösterdiği söylenebilir; çünkü en yüksek beylerbeyi olan Rumeli Beylerbeyi, ancak görev yerinden ayrılıp İstanbul'a gelirse Divan-ı Hümayun toplantılarına katılır ve bir merkez yöneticisi gibi çalışırdı. ${ }^{21}$

Kaptan Paşa'nın Divan-ı Hümayun'dan başka değişik divanlarda da görevi bulunmaktaydı. Bu divanlar içinde en önemlisi, kuşkusuz Vezir-i Azam'ın Divanı olan İkindi Divanıyd. Divan-ı Hümayun'da karara bağlanması gereksiz görülen işler ile doğrudan doğruya Vezir-i azam'ın çalışma alanına giren işler İkindi Divanı'nda görüşülürdü. Divan-ı Hümayun toplantılarının öğle vaktine kadar bitirilmesi kanun olduğu için, orada görüşülemeyen konular da İkindi Divanı'nda karara bağlanır, ancak daha sonradan tekrar Divan-1 Hümayun'da görüşülebilirdi. ${ }^{22}$ Divan-1 Hümayun'un tam anlamıla işlediği dönemlerde rolü önemsiz olan İkindi Divanı Divan-1 Hümayun'un XVII. yüzyıldan itibaren silikleşmeye başlaması üzerine bu divanın yerini almıştır. ${ }^{23}$

İkindi Divanı'na Nişancı hariç, Divan-1 Hümayun'a katılan üyelerin ihtiyaca göre hepsi ya da bir bölümü katılırdı. Bu görevliler arasında kuşkusuz Kaptan Paşa'nın da adı vardır.

Öte yandan Kaptan Paşa'nın, hemen karara bağlanması gerekli, çok ivedi ve önemli bir durumla karşılaşıldığı zaman Padişah başkanlığında toplanan Ayak Divanı'nda da yeri bulunmaktaydı; çünkü bu divanda Divan1 Hümayun üyeleri ve gerekli görülen tüm devlet adamları hazır bulunurdu. ${ }^{24}$

Yine, çok büyük bunalım anlarında Padişah veya Vezir-i azam'ın, devlet yönetiminde çalıșan ve çalışmıș tüm belli başlı görevlileri topladı̆̆ı ve herkesin görüşünü serbestçe söyleyebildiği Meşveret Yöntemi'nde ${ }^{25}$ de Kaptan Paşa'nın yerinin olacağı tartışılmayacak kadar açıktır.

${ }^{20}$ MUMCU; a.g.e., s.55

${ }^{21}$ ÜÇOK - MUMCU - BOZKURT; a.g.e., s.209 - AYDIN, M. Akif; Türk Hukuk Tarihi, İstanbul, 1999, s.142.

22. "İkindi Divanı" ile ilgili ayrıntılı bilgi için bkz.; CIN, Halil - AKGÜNDÜZ, Ahmet; Türk Hukuk Tarihi, C.: I, Konya, 1989, s.203 - UCÇK - MUMCU - BOZKURT; a.g.e., s.215 UZUNÇARŞILI; Osmanlı Devleti'nin Merkez ve Bahriye Teşkilâtı, s.136.

${ }^{23}$ MUMCU; a.g.e., s.142,143.

${ }^{24}$ Bu divan, Padişah'ın karşısında hiç kimse oturamayacağı için "Ayak Divanı” adını almıştır. Ayak Divanı ile ilgili ayrıntılı bilgi ve bir örnek için bkz., UZUNÇARŞILı, İsmail Hakkı; Osmanlı Devleti'nin Saray Teşkilâtı, Ankara, 1988, s.225,226.

${ }^{25}$ Meşveretin toplanmasıyla ilgili ayrıntılı bilgi için bkz, SHAW, S.J.; Between Old and New, Cambridge, 1971, s.73-MUMCU; a.g.e., s.160. 
Kaptan Paşa'nın Tersane'de de davalara bakma görevinin bulunduğu anlaşılmaktadır. Kaptan Paşa bir davayı kendisi çözümleyebileceği gibi, lïzum gördüğünde onu kadı mahkemesine de havale edebilirdi.

Kaptan Paşa donanma ile sefere çıktığı zaman da, kendi huzurunda ceza ve hukuk davalarını dinler, onları karara bağlardı. Donanmada bir de kadı bulunur, Şer'î hükümleri o verirdi. ${ }^{26}$

Gelinen bu noktada, Kaptan Paşa'nın "Siyaseten Katl" yetkisinden de söz etmek gerekmektedir. Bilindiği gibi İslâm Devleti hükümdarlarına, devlete zararlı oldukları kanısına vardıkları kimseleri öldürebilmeleri yolunda bir hak tanınmıştır. "Siyaseten Katl" adı verilen bu hakkın kullanılabilmesi için Şeyhülislâm'dan bir fetva alınmaktadır. ${ }^{27}$ Osmanlı Devleti'nde Siyaseten Katl yetkisi tamamen Padişah'a ve bazı istisnalarla onun mutlak vekili olan Vezir-i azam'a aittir. Diğer devlet adamları, bu nedenle takdir haklarını kullanarak doğrudan "siyaset" emri veremezler. Bu konuda onlara Padişah veya Vezir-i azam tarafından yetki verilmiş olmalıdır. ${ }^{28}$

Devletin yüksek memurlarından ve en yetkililerinden biri olarak Kaptan Paşa da, Padişah veya Vezir-i azam'dan aldığı yetkiye dayanarak, sefer sırasında gerekirse idam hükmünü verebilirdi. Şüphesiz barış zamanında da, tersane bölgesinin asayişini sağlamak üzere Siyaseten Katl yetkisini kullanabilirdi. ${ }^{29}$

Görüldüğü gibi, Kaptan Paşa'nın çeşitli divanlarda yargılama yetkisi mevcuttur. Denizcilik gibi oldukça önemli bir alandaki yargılama yetkisinin Kaptan Paşa tarafından kullanılması bir yandan devlet işlerinde işbölümünün başarıyla uygulandığını göstermekte, bir yandan da devletin düzenli bir hiyerarşiye tabi olduğunu kanıtlamaktadır.

\section{B. Donanmaya Komuta Etmek}

Osmanlı Devleti'nin ilk zamanlarında Padişah veya Vezir-i azam'ın, onlar savaşa katılmadıkları zaman ise "Serdar" tayin edilen bir vezirin donanmaya komuta ettiği görülmektedir. Zamanla Akdeniz ve Karadeniz'in Türk egemenliğine girmesiyle donanmanın önemi artmış, kaptan paşalar da deniz savaşlarının komutasında yer almaya başlamışlardır. Bir süre "Serdar" olarak donanmanın başına atanan vezirin emri altında, çifte kumanda sistemi içinde görev yapan kaptan paşalar, bu sistemin

\footnotetext{
${ }^{26}$ UZUNÇARŞILI; Osmanlı Devleti'nin Merkez ve Bahriye Teşkilâtı, s.417.

${ }^{27}$ ÜÇOK-MUMCU-BOZKURT; a.g.e., s.82.

${ }^{28}$ MUMCU, Ahmet; Siyaseten Katl, Ankara, 1963, s.83.

${ }^{29}$ PARMAKSIZOĞLU; a.g.m., s.208- UZUNÇARŞILI; Osmanlı Devleti'nin Merkez ve Bahriye Teşkilâtı, s.417.
} 
zararlarının anlaşılması üzerine, zamanla donanmanın tek yetkili kişisi durumuna yükselmişler ve komutasını üstlenmişlerdir. ${ }^{30}$

Donanma'nın başkomutanı olarak Kaptan Paşa herşeyden önce II. Beyazıt döneminden itibaren Doğu Akdeniz'de ticaret güvenliğini sağlamakla görevlendirilmiştir. Bu sebeple her yıl Rûz-i Hızır'ı müteakip donanma ile Akdeniz'e açılan Kaptan Paşa, Fas'a kadar tüm sahilleri tarayarak eyaletinin sancaklarını kontrol eder, bu arada korsanları da izleyip İstanbul'a dönerdi. XVII. yüzyılda Karadeniz'de Rus ve Kazak korsanlarının türemesi üzerine, Karadeniz'in emniyetinin sağlanması görevi de Kaptan Paşalara verilmiştir.

Deniz savaşı sırasında Kaptan Paşa'nın donanma ile birlikte savaş alanında bulunması zorunluydu. Kaptan Paşa ihtiyaca göre, bazen kara seferinde de görevlendirilebilirdi. Buna karşılık deniz seferlerine çıkılacağı zaman deniz kuvvetlerinden başka askerî birliklere de ihtiyaç duyulabilir, ancak bu durumda onların komutası, Kaptan Paşa'dan daha kıdemli olan Donanma Serdarı'na bırakılırdı. Kaptan Paşa ise sadece kendi mensuplarının idaresinden sorumlu sayılır, yetkilerini aşması onun görevinden azli sonucunu doğururdu. ${ }^{31}$

Kaptan Paşa komutasındaki Osmanlı deniz kuvvetleri başlica iki sınıfa ayrılmaktaydı: Bu sınıflardan biri sanatkârlardı. Tersane'nin esas erkânı sayılan sanatkârlar kaptanlar, reisler, kalafatçılar, kumbaracılar, marangozlar gibi sanat erbabından oluşmaktaydılar. Onlara "Tersane Ricâli" de denilmekteydi. Bu sınıfın maaşları diğer çalışanlara göre yüksek ve dolgundu.

Diğer sınıf ise gemilerdeki cenkçi askerlerdi ki, onlara "Azap" adı veriliyordu. Gemilerin kürekçileri ise mahkumlardan, esir edilen Hristiyanlar'dan oluşmaktaydı. Harp sırasında donanmaya cenkçi olarak Yeniçeri ve Cebeciler'in de ilâve edildikleri görülmektedir. ${ }^{32}$

Kanunî Sultan Süleyman döneminde merkezi Gelibolu Sancağı olmak üzere Kaptan Paşa Eyaleti kurulmuş, bu büyük eyalete bazı sancaklar dahil edilmiştir. ${ }^{33}$ Kaptan Paşa Eyaleti'ne bağlı bulunan bu sancaklardan savaş sırasında donanma hizmetine 4000-4500 kadar asker gelir, bunlar Kaptan-1 Derya Kalemi'ne kaydolunurlardı. Azapların da ilâvesiyle o tarihlerde bahriye askerlerinin sayısı 6000 'i geçkin olarak hesaplanmıştır. ${ }^{34}$

\footnotetext{
31) GENCER; a.g.e., a.g.e., s.15,16.

31 PARMAKSIZOĞLU; a.g.m., s.209.

${ }^{32}$ GENCER; a.g.e., s.15,16.

${ }^{33}$ Bu sancaklar Gelibolu, Eğriboz, İnebahtı, Midilli, Sığacık, Kocaeli, Mora'da Karlı Illi ve Mezestre, Sakız, Trablusgarp'ta Mehdiye, daha sonra da Kıbrıs olarak sıralanabilir.

${ }^{34}$ GENCER; a.g.e., s.16.
} 
Donanma komutanı olan ve amiral durumundaki Kaptan Paşa'dan sonra donanmayı oluşturan filoların komutanlıklarını Beylerbeyi ve Sancakbeyleri yapmaktaydlar. ${ }^{35}$

Görüldügui gibi Osmanlı Donanması Kaptan Paşa komutasında düzenli bir hiyerarşiye tabiydi ve bütün işler bir sistem içinde işlemekteydi.

\section{Tersanede Düzenlenen Çeşitli Törenlerde Teşrifat Kurallarmı Uygulamak}

Kış mevsimini tersanede geçiren donanmanm bahar ile birlikte denize açılması, tersanede donanma için yeni bir geminin yapılmasına başlanması veya bitirilmesi, Padişah için filika yapımının tamamlanması gibi çeşitli durumlarda Padişah ve Vezir-i azam'ın da katıldı̆̆ı çeşitli törenler diizenlenir, bu törenlerde Kaptan Paşa önemli teşrifat kurallarını uygulardı.

Donanmanın denize açılması müneccimbaşının hava şartlarını hesap ve tahminle belirlediği uygun bir zamanda olurdu..$^{36}$ Müneccimbaşmin belirlediği zaman bir pusula ile Bâb-1 âlî'ye bildirilir, Vezir-i azam'ın da onayıyla tören hazırlıkları başlardı. Tören genellikle Yalı Köşkü’nde yapllırdı. Birkaç gün öncesinden tören için devlet ricâline Dolmabahçe'de çadırlar kurulur, Köşk Padişah için döşenerek törene hazır hale getirilirdi. Törenden bir gün önce Teşrifat Kalemi'nden yazılan "vakt-i muhtar" ve "sa'at pusulası" Reisülküttap Kîsedârı aracılı̆̆ı ile Şeyhülislâm'a, Sadaret'ten yazılan tezkireler de teşrifatçılar aracılığı ile vezirlere ulaşturılırdı. Defterdara da Sadaret Kethüdası tarafından tezkire yazılarak gönderilirdi. Böylece törenin daveti tamamlanmış olmaktadır. Tören günü Reisülküttap Şeyhülislâm'ı konağına giderek alır ve tören mahalli olan Yalı Köşkü'ne götürürdü. Onların Köşk'e vardıkları haberi Bâb-ı âlî'ye gelince, Vezir-i azam da kapı takımı ile birlikte Köşk'e hareket ederdi. Herkes yerleştikten sonra Padişah sandalla gelir, İskele'de Reisülküttap, Defterdar ve Rikab-ı Hümayun Ağaları tarafından karşılanır ve Köşk’e götürülürdü. Ardından Tersane'de beklemekte olan Kaptan Paşa'ya haber salınıp gelmesi istenirdi. Kaptan Paşa'nın gelmesini müteakip Vezir-i azam ile ikisi Köşk’te arza girerler, hilât giydirilmesinden sonra Kaptan Paşa döner ve Donanma'nın başındaki yerini alırdı.

Bir süre sonra Vezir-i azam Şeyhülislâm ile birlikte Baștarde-i Hümayun'a gider, toplar atılır ve Osmanlı Donanması Dolmabahçe önünden geçiş merasimini gerçekleştirirdi. Ardından Vezir-i azam ve Şeyhülislâm kendileri için kurulan çadıra geçerler ve burada Padişah

\footnotetext{
36 GENCER; a.g.c., s.17.

${ }^{36}$ Osmanlı Devleti İsłâm ilkeleriyle yönetilen bir devlet olduğu halde, böyle bir uygulamanın eski Türkler'deki "Samanizm” geleneklerine benzerliği dikkat çekmektedir. Şamanizm dininde kamların devlet düzenine etkileriyle ilgili ayrıntılı bilgi için bkz.; INAN, Abdulkadir; Tarihte ve Bugün Şamanizm, Ankara, 1995, s.72 vd.
} 
huzurunda hilât giyme töreni başlardı. Bu arada merasim sonrası karaya çıkan Kaptan Paşa da kendi çadırına geçer, bir süre dinlendikten sonra Vezir-i azam'ın çadırını ziyaret eder, orada önce kendisine, ardından da Tersane Ricâli'ne hilât giydirilirdi. Hilât törenini takiben de Kaptan Paşa ile Vezir-i azam bir süre sohbet ederler, kendilerine güllâb ve buhur ikram edilir, derken Kaptan Paşa gider ve tören sona ermiş olurdu.

Kaptan Paşa donanma ile denize açılacağı zaman, eğer tersanede bir tören düzenlenmeyecekse, veda için Bâb-1 âlî'yi ziyaret ederdi. Bâb-1 âlî Ricâli Kaptan Paşa'yı merdiven başında karşılar, ardından da orta odada bulunan Vezir-i azam'ın yanına götürürdü. Ricâl temenna ederek çıkar, Kaptan Paşa'ya peşkir ile birlikte tatlı, kahve, çubuk, şerbet, güllâb ve buhur takdim edilir, kendisine serâsere sarılmış samur kürk giydirilirdi. Oradan çıkışında Kaptan Paşa Reisülküttap Efendi'nin ve Kethüda Bey'in odasına da uğrar, en son da Şeyhülislâm Efendi'ye giderdi.

Donanma'nın gidişi gibi dönüşünde de bir tören düzenlenirdi. Bu törende, ilk törenden farklı olarak önce Padişah Yalı Köşkü'ne gider, Şeyhülislâm ise Bâb-1 âlî'ye gelerek Vezir-i azam ile birlikte sonradan Köşk'e çıkarlardı. Bu fark dışında iki tören birbirine çok benzemektedir. Öte yandan, yapımı yeni bitmiş bir kalyonun veya Padişah için kayıkhanede inşa edilen bir sandal ya da filikanın denize indirilmesi törenleri de sıkı teşrifat kurallarına göre icra edilmekte, Kaptan Paşa'ya bu törenlerde de önemli yetki ve sorumluluklar düşmekteydi. ${ }^{37}$

Denilebilir ki, sefere çıkılırken ya da seferden dönülürken düzenlenen törenler ve uygulanan teşrifat kuralları, devletin öteden beri sürdürülegelen geleneklerine ne derece bağlı kalındığını kanıtlamaktadır. Bunlar birer Kamu Hukuku geleneği olarak yerleşmiş ve yüzyıllarca sürdürülmüşlerdir.

\section{Padişah veya Vezir'i azam'ın Denetlemelerinde Teşrifat Kurallarını Uygulamak}

Kaptan Paşa'nın diğer bir görevi de, Padişah veya Vezir-i azam'ın Tersane'yi ziyaretleri sırasında uygulanan çok sıkı teşrifat kurallarıyla ilgilidir. Kaptan Paşa'nın bu kuralların uygulanmasında da büyük sorumluluğu bulunmaktaydı.

Padişah ve Vezir-i azam hem tersanedeki mühimmatın durumu hakkında fikir edinmek, hem de inşası devam etmekte olan kalyonların hangi aşamada olduklarını öğrenmek üzere zaman zaman Tersane'yi ziyaret eder ve incelemelerde bulunurlard..$^{38}$ Padişah'ın ziyarete geleceği

\footnotetext{
${ }^{37}$ Donanmanın denize açılması veya seferden dönmesi scbebiyle düzenlenen törenler ve uygulanan teşrifat kuralları ile ilgili ayrıntılı bilgi için bkz: AHISHALI, Recep: Osmanls Devlet Teşkilâtında Reisülküttaplık, İstanbul, 2001 , s.312 vd.

${ }^{38}$ ÜÇOK-MUMCU-BOZKURT; a.g.e., s.208.
} 
bir gün öncesinden Vezir-i azam'a haber verilir, O da akşamdan durumu Kaptan Paşa'ya bildirirdi. Ertesi gün Vezir-i azam kapı ricâli ile birlikte Tersane'ye giderek hazır bulunurdu. Padişah'ın sandalla gelmekte olduğu haber verilince, Vezir-i azam, Kaptan Paşa, Reisülküttap, Çavuşbaşı ve Rikab-ı Hümayun Ağaları O'nu iskele başında karşılarlar ve peşinden yürüyüp Divanhane Kasrı'na getirirlerdi. Vezir-i azam ve Kaptan Paşa burada arza girerler, arzdan sonra ise Padişah mahzenleri gezerdi. Bu sırada Reisülküttap, Çavuşbaşı, Rikab-1 Hümayun Ağaları, Kaptan Paşa ve Vezir-i azam'ın, ellerinde sedefkârî asalar ile Padişah'ın peşinden yürümeleri adettendi. Bundan sonra ise Tersane Bahçesi'ne geçilir, orada Tersane Ricâline verilecek atiyye Kaptan Paşa'ya teslim olunur ve tören biterdi. ${ }^{39}$

Vezir-i azam'in da zaman zaman Tersane'yi gezmesi ve denizcilik işlerini denetlemesi kanundu. Kaptan Paşa Vezir-i azam'ın gelişinde, O'nu iskele üzerinde karşılar ve taşıdığı sedefli asasını O'na verirdi. Vezir-i azam'ın önüne düşüp Tersane'yi gezdiren Kaptan Paşa, kendisine denizcilik işleri ile ilgili gerekli bilgileri verirdi.

Kaptan Paşa ayrıca İstanbul'da bulunduğu sırada, her Cuma Namazı çıkışında Paşa Kapısı'na gelip arz odasında Vezir-i azam'la, eğer Vezir-i azam seferde ise Sadaret Kaymakamı'yla görüşür, arzuya göre haftada ya da iki haftada bir de Sadaret Kethüdası'nın odasına uğrardı. ${ }^{41}$

$\mathrm{Bu}$ açıklamalar göstermektedir ki, Kaptan Paşa da diğer devlet görevlileri gibi her an çok sıkı takip edilmektedir. Donanma teşkilâtının sürekli biçimde güçlü ve göreve hazır tutulmasının önemi böylece ortaya çıkmaktadır.

\section{E. Diğer Görevleri}

Kaptan Paşa Bahriye'ye ait büyük küçük her türlü tayinden de sorumluydu. Ayrica Derya Kalemi'ne ait olan zeamet ve tımarların dağıtımını de tek başına yapabilirdi. Ancak ilk defa verilecek tımarlar için Vezir-i azam'a telhis sunmak zorundaydı. Öte yandan, alanı ile ilgili önemli bazı işleri de Vezir-i azam'a arz etmesi gerekiyordu. Bu ve bunun gibi birkaç sınırlama dışında, Kaptan Paşa'nın denizcilikle ilgili pek çok konuda Padişah adına hüküm yazmaya ve tuğra çekmeye yetkili olduğu görülmektedir. ${ }^{41}$

Kaptan Paşa Tersane'nin bulunduğu Haliç ve çevresinin asayişinden de sorumlu idi. Her gece, onun emrindeki kaptanlardan otuzbeşi, yanlarında

${ }^{39}$ UZUNÇARŞıLI; Osmanlı Devleti'nin Merkez ve Bahriye Teşkilâtı, s.416 - AHISHALI; a.g.e., s.314.

4) UZUNÇARŞILI; Osmanlı Devleti'nin Merkez ve Bahriye Teşkilâtı, s.416,417.

${ }^{41}$ Kaptan Paşa'nun bu görevleri ile ilgili aynntılı bilgi için bkz.; UZUNÇARŞıLI; Osmanlı Devleti'nin Merkez ve Bahriye Teşkilâtı, s.415. 
üçyüz kadar deniz piyadesi olduğu halde bölgede nöbet tutar ve sokakları dolaşırdı. ${ }^{42}$

Bütün görevleri bir arada düşünüldüğünde denilebilir ki; Kaptan Paşa Padişah'ın mutlak egemenlik yetkisini kullanan bir kamu görevlisi olarak oldukça geniş yetkilerle donatılmış, O'na görevini gereği gibi yerine getirebilmesi için büyük bir serbesti tanınmıştır. Fakat sonuçta kendisinin de merkezî otoriteye sıkı sıkıya bağlı bir görevli olduğu unutulmamalıdır. Bu görünüşüyle Kaptan Paşa, diğer "Ulema Dışı Askerîler" gibi her an görevden alınabilir ve değiştirilebilirdi. Osmanlı devlet teşkilâtındaki diğer görevliler gibi, onun makamı için de bir garanti ya da güvence söz konusu değildi.

\section{KAPTAN PAŞALIK MAKAMI'NA VEKÂLET}

Kaptan Paşa İstanbul'da bulunurken kendisine Akdeniz'de Rodos Beyi vekâlet ederdi. Bu mevki filo komutanları arasında Kaptan Paşa'dan sonra en yüksek makam olup, oradan Kaptan Paşalığa yükselebilmek mümkündü. Örneğin 1644-1645 yılları arasında Kaptan Paşalık yapan Ebu Bekir Paşa'nın durumunda olduğu gibi.

Kaptan Paşa'nın İstanbul'daki yardımcısı ise Tersane Kethüdası idi. $\mathrm{Bu}$ kişiyi önceleri Kaptan Paşa seçerken, zaman içinde Kethüdalı̆̆ın öneminin artması üzerine bu kişi artık merkezden atanmaya başlanmıştır. Zaman zaman Tersane Kethüdalığı'ndan Kaptan Paşalığa geçen kişilere de rastlanmaktadır. Örneğin 1642-1643 yılları arasında Kaptan Paşa olan Uzun Piyale Paşa bunlardan biridir.

Tersane Kethüdalı̆̆ı III.Selim döneminde 1804 Bahriye Kanunnamesi ile "Umûr-i Bahriye Nazırlığı" ismini almış, IV.Mustafa döneminde ise bu kurum geliştirilmiştir. Halil Rıfat Paşa'nın Kaptan Paşalığında "Tersane Müdürlüğ̈̈" şekline konulan Kethüdalık, Firârî Ahmet Fevzi Paşa'nın Kaptan Paşalığı zamanında da (1836-1839) Bahriye Müsteşarlığı'na çevrilmiştir. ${ }^{43}$

Görüldüğü gibi, Osmanlı merkez örgütünde yer alan tüm memurluklarda olduğu gibi Kaptan Paşa'nın da düzenli bir hiyerarşiye tâbi çeşitli yardımcıları bulunmaktadır. Bu kişiler görev ve sorumlulukları çok geniş olan Kaptan Paşa'nın iş yükünü hafifletmektedirler.

\section{KAPTAN PAŞA EYALETI}

Kaptan Paşa Eyaleti'ne "Cezayir Eyaleti” de denmekteydi; çünkü eskiden Cezayir Sultanı olan Barboros Hayrettin Paşa Osmanlı Devleti'nin

\footnotetext{
${ }^{42}$ ANADOL, Cemal - ABBASOVA, Fâzile; Türk Kültür ve Medeniyeti, İstanbul, 2002, s.578.

${ }^{43}$ PARMAKSIZOĞLU; a.g.m., s.208, 209.
} 
hizmetine girdikten sonra, kendisine ait olan Cezayir yine üzerinde bırakılmış ${ }^{44}$ ve bir süre Kaptan Paşalık bu eyaletle birlikte dağıtılmıştır. Barbaros döneminden önce ise Kaptan Paşalığın merkezinin Gclibolu olduğu bilinmektedir. $^{45}$

Kaptan Paşa Eyaleti de diğer eyaletlerde olduğu gibi çeşitli sancaklardan meydana geliyordu ve bu sancaklar devletin sinurlarının genişlemesine paralel olarak XVII. yüzyılda hash ve salyâneli olarak iki kısma ayrılmışlardı. Bunlardan Gelibolu-A ğrıboz, İnebahtı, Midilli, Sı̆̆acık, Kocaeli, Karlıeli, Rodos, Biga ve Mezistre sancakları haslı; Sakız, Nakşe (Naksos) ve Mehdiye sancakları ise salyâneli (yani yıllıklı) sancaklardı. Kaptan Paşa Eyaleti'nin sinırları ve bu eyalete bağlanan sancaklar devletin sonraki dönemlerinde çeşitli toprak kayıpları ya da yapılan kanunî düzenlemeler sonucunda değişikliklere uğramıştır. ${ }^{46}$

Kaptan Paşa Eyaleti'nin sancaklarından Sı̆̆la Sancağı (lzmir ve yöresi) Tersane Kethüdesı'nın hasıydı. Bir başka deyişle Sı̆̆la'nın sancakbeyi aynı zamanda Tersane Kethüdası idi; ama bu kişinin görev yeri İstanbul'daydı. ${ }^{47}$

Kaptan Paşa Eyaleti'nin sancakbeyleri tımarlı sipahi ve zaimleriyle birlikte donanma ile sefere katılmak zorundaydılar; ancak sefer için daha fazla askere ihtiyaç duyulduğu zamanlarda, Kaptan Paşa Eyaleti'ne bağlı olmayan sancaklardan da deniz seferine asker alındığı olmuştur.

Kaptan Paşa Eyaleti'ne bağlı sancakbeylerine "Derya Beyleri" adı verilmekteydi. Bunlar sefer zamanlarında kendi has ve salyânelerine göre birer, ikişer ya da üçer kadırga ile Donanma'ya katılırlardı. Böylece XVII. yüzyılın ortalarında, bir deniz seferine sadece Kaptan Paşa Eyaleti'ne bağlı sancaklardan 138 zaim ve 1434 tımarlı sipahi ve 4500 kadar cebelinin katılabildiği hesaplanabilmektedir. ${ }^{48}$

Görüldüğü üzere Kaptan Paşa aynı zamanda bir eyalet yöneticisidir. Kendi eyaletine bağlı her bir sancak düzenii bir hiyerarşi içinde Kaptan Paşa'nın sıkı denetimine tabi tutulmuştur. Kaptan Paşa Eyaleti'ne bağlı her bir sancağm sefer sırasında belli sayıda gemi ve asker sağlama zorunluluğu, Osmanlı Donanması'nın tıpkı kara ordusu gibi oldukça düzenli bir şekilde işlediğini göstermektedir.

\footnotetext{
${ }^{4}$ Barbaros Hayrottin Paşa'nun Kaptan Paşa seçilmesi ile ilg̨ili ayruntıl bilgi için bkz., YUCEL - SEVIM; Fatih - Yavuz - Kanunî, s.185 vd.

4' UZUNÇARŞIL.I; Osmanlı Devleti'nin Merkez ve Bahriye Teşkilâtı, s.420.

th Çeşitli dönemlerde Kaptan Paşa Eyaleti'nin ve ona bağlı sancakların smurian ile ilgili aynntılı bilgi için bkz.;PARMAKSIZOC̆LU, a.g.m., s.208 vd.

47 UZUNÇARŞILI; Osmanlı Devleti'nin Merkez ve Bahriye Teșkilâtı, s.420.

${ }^{48}$ UZUNÇARŞILI; Osmanlı Devleti'nin Merkez ve Bahriye Teşkilâtı, s.422.
} 


\section{KAPTAN PAŞA'NIN GELIRLERI}

Kaptan Paşa'nın çeşitli gelirlerinden söz edilebilir. O'nun en önemli geliri kendisine tahsis edilen hası idi. ${ }^{49}$ XVII. yüzyılda Kaptan Paşa'nın hasının senelik geliri 888.500 Akçe idi. Bu gelirinin yanısıra Kaptan Paşa Eyaleti'nde yer alan adalardan otuzüç küçük adanın da voyvodalara iltizama verildiği ve oradan varidat alındığı bilinmektedir. Bu yolla Kaptan Paşa'nın elde ettiği gelir, yine XVII. yüzyılın rakamlarıyla 70.000 Kuruş (o tarihte 80 Akçe 1 Kuruş idi.) olarak hesaplanmıştır. Bu rakam XVIII. yüzyılın sonlarında 300.000 Kuruş'a kadar çıkmıştır. İltizam gelirinin bir miktarı Maliye Hazinesi'ne girer, geriye kalan kısmı ise Kaptan Paşa'ya bırakılırdı. Kaptan Paşa'nın bir diğer geliri ise, donanmada görevi olan ya da yeni tayin edilen en küçüğünden en büyüğüne kadar tüm memurların ödemek zorunda oldukları "caize" denilen paralardan oluşuyordu. ${ }^{50}$ XVIII. yüzyılda kaptan paşalar bu gelirlerinden ayrı olarak malikâne sahibi de olmuşlardır. ${ }^{51}$

Gelirleri bu derece çeşitli ve bol olan kaptan paşaların harcamaları da ona göre fazlaydı. Padişah'a, Valide Sultan'a, kadın efendilere her sefer dönüşünde büyük hediyeler getirirlerdi. Bu arada sefere giderken ve sefer dönüşlerinde, Yah Köşkü'nde Padişah'ın huzuruna kabul edilirlerken Yalı Köşkü'nün döşeme bedeli olarak Padişah Hazinesi'ne (İç Hazine'ye) 20.000 Kuruş (XVIII. yüzyıl rakamlarıla) ödemeleri de adettendi.

Kaptan Paşa'ya, bir eyalet yöneticisi olması itibarıyla, diğer eyaletlerin yöneticileri olan beylerbeyleri gibi, kendi hasının gelirleriyle orantılı olarak asker yetiştirme ve bu askerlerle sefere çıkma zorunluluğu da getirilmiştir. Böylece XVII. yüzyılda kaptan paşaların, sadece kendi haslarından çıkardıkları cebeli asker sayısının 1000 kadar olduğu tespit edilmiştir. ${ }^{52}$

Dikkat edilirse, Kaptan Paşa bir deniz seferine çıkarken hem kendi eyaletine bağlı sancakların herbirinden, hem de kendi hasından belli sayılarda cebeli asker çıkarmak ve bunları savaşa götürmek konularında devlete karşı sorumlu tutulmuştur.

\section{KAPTAN PAŞALIĞIN ORTADAN KALKIŞI ve BAHRIYYE NEZARE'TI'NIN KURULUŞU}

Osmanlı merkez teşkilâtında yaklaşık beşyüz yıllık bir geçmişi olan Kaptan Paşalık kurumu, yukarıda anlatılan şekliyle 8 Nisan 1867 (3 Zilhicce 1283) tarihine kadar devam etmiş; bu tarihte Bahriye Nezareti

\footnotetext{
${ }^{49}$ Bilindiği gibi yıllık geliri 100.000 akçenin üzerinde olan dirlikler "HAS" adıyla anılırlardı. UCCOK-MUMCU-BOZKURT; a.g.e., s.223.

"U UZUNÇARŞILI; Osmanlı Devleti'nin Merkez ve Bahriye Teşkilâtı, s.417.

51 PARMAKSIZOĞLU; a.g.m., s.209.

s2 UZUNÇARŞILI; Osmanlı Devleti'nin Merkez ve Bahriye Teşkilâtı, s.417.
} 
kurularak bir değişikliğe gidilmiştir. Bu, Tanzimat Dönemi'nde denizcilik alanında Bahriye Meclisi ${ }^{53}$ nin kurulması yanında, yapılan en önemli reform sayılmaktadır.

Kaptan Paşalığın kaldırılması fikri ilk olarak 1845 'de ortaya atılmıştır. Bu tarihte Kaptan Paşalığın yerine "Bahriye Müşirliği” denilmesi gündeme gelmişse de, bu teklif o zamanlar pek dikkate alınmamış; "Kaptan Paşa" unvanı Bahriye Nezareti'nin kurulmasına kadar sürdürülmüştür. ${ }^{54}$

XIX. yüzyılın başından itibaren Kaptan Paşalığın iş yükünün gereğinden fazla artmasi ${ }^{55}$, bu makamın temel görevi olan denizcilik konusuna yeterince eğilememesi sonucunu doğurmuş; böylece kaptan paşaların görevlerinde bir kısıntıya gidilmesi zorunluluğu belirmiştir. Bu durumu gözönüne alan Sadaret Makamı 11 Mart 1867 (5 Zilkade 1283)'de bir takrir hazırlayarak, bundan böyle Kaptanlık Makamı'nın sadece Donanma-yı Hümayun'un komutasında olmasını, denizcilikle ilgili idarî ve malî konuların ise, yeni kurulacak Bahriye Nezareti tarafından yürütülmesini öngörmüş; ayrıca Bahriye Nazırı olarak Hazine-i Hassa Nazırı Hakkı Paşa'nın ilâve-i memuriyet olarak tayin edildiğini belirterek, durumu dönemin Kaptan Paşası Damat Mehmet Ali Paşa'ya bildirmiştir.

Böylece, ortaya çıkan yeni uygulamayla Tersane-i Âmire'nin idarî ve malî işleri Bahriye Nezareti'ne verilmiş, donanma komutanlığ görevi ise Kaptan Paşa'da bırakılmıştır. Bu düzende ayrıca, Kaptanlık Makamı'nın (Kaptan Paşalığın) Bahriye Nezareti’ne bağlı kalması öngörülmüşs, Tersane ve Donanma'nın her türlü işinin Bahriye Nazırı tarafından tespit edilerek,

53. Tanzimat Dönemi'nde Kaptan Paşa'ya Tersane ve Donanma'nun her türlü sorunu ile ilgili reform tespit çalışmalarını yürütmede yardımcı olmak üzere, bahriyenin önde gelen görevlilerinden oluşan bir Bahriye Meclisi oluşturulmuş, bu sayede denizcilik alanında yapılan reformlar önemli ölçüde istikrara kavuşturulmuştur.

Bahriye Meclisi 1864'de (1281) Bahriye, Nizam ve Levazım Daireleri'ne ayrılarak bahriyc işlerini yürütmeye çalışmıştır. Sözü edilen dairelerin, görevleri ile ilgili olarak hazırladığı raporların Bahriye Meclisi'nde toplanması ve gözden geçirildikten sonra Meclis Mazbatası şeklinde tespit edilip Kaptan Paşa'ya sunulması esası benimsenmiştir. Ancin Ka aptan Paşalığın 1867'de kaldırılmasından sonra bu sunma işi Bahriye Nazırı'na yapılmaya başlanmıştır. Nezaret'in kurulmasından sonra Bahriye Meclisi'ne bir takım kalemler, ayrıca "Islahat Komisyonu" adıyla bir de komisyon ilâve edilmiştir. Bu komisyon Tersane-i Âmire'nin genel ıslahatını müzakere etmek, gerekli düzenlemeleri yapmak ve onların yürütülmesi ile meşgul olmak gibi önemli görevleri üstlenmiştir. (Konu ile ilgili ayrıntılı bilgi için bkz.; GENCER; a.g.e., s.328,329.)

s4 UZUNÇARŞILI; Osmanlı Devleti'nin Merkez ve Bahriye Teşkilâtı, s.420.

${ }^{55}$ Donanma'nın malî ve idarî konulardaki sorunlarını çözmede Kaptan Paşa'ya öteden beri yardımcı olmakta olan Bahriye ve Tersane Müsteşarlığı'nın 1861'de kaldırılması üzerine, donanmanın malî sorumluluğunu da üzerlerine alan Kaptan Paşalar, böylece denizcilik alanında hem idarî, hem malî, hem de askerî işleri tek başlarına üstlenmek durumunda kalmışlardır. Diğer taraftan onlara ilâve bazı memuriyetlerin de verilmesiyle işleri iyice güçleşmiştir. (GENCER; a.g.e., s.316 vd.) 
Heyet-i Vükelâ'nın tetkikine sunulmak üzere Bâb-1 âlî'ye bildirilmesi esası benimsenmiştir. Görüldüğü üzere denizcilik işlerinde yüzyıllardan sonra ilk kez Kaptan Paşalık dışında ve üzerinde bir makam kurulmuş olmaktadır.

Sadaret Makamı'nın düzenlemesi ile, denizcilik alanındaki askerî ve idarî işler için Bahriye Nezareti'ne bağlı iki ayrı meclisin de oluşturulduğu görülmektedir. Düzenlemeye göre bu meclislerden askerî işleri yürüten Kumanda Meclisi'nin üzerinde Kaptanlık Makamı bulunacak, ama o da Bahriye Nezareti'ne bağlı olacaktı. Öte yandan Kumanda Meclisi'nin, yaptığı işlerle ilgili olarak Kaptanlık Makamı'na sunduğu raporların Kaptan Paşa ve Bahriye Nazırı tarafından müştereken karara bağlanması öngörülmüştür. Bu usul, Bahriye Nezareti'nin kuruluşundan bir ay sonra Kaptanlık Makamı'nın kaldırılması üzerine değişmiş; Kumanda Meclisi de, diğer meclis (İdare Meclisi) gibi doğrudan Nezaret'e bağlanmıştır. ${ }^{56}$

Bu yenilikleri müteakip Bahriye Nazırı Hakkı Paşa yeni teşkilâtta Kaptanlık Makamı'nın (kaldırılmadan önceki dönem) ve Bahriye Nezareti'nin görevlerini belirten iki ayrı nizamname hazırlayarak bunları Sadaret'e sunmuş; Sadaret Makamı da bu nizamnameleri Padişah'a arz etmiştir. Padişah'ın da kabul ettiği nizamnamelerden Bahriye Nezareti'ni düzenleyen nizamname, Nezaret'in görevlerini şöyle sıralamıştır:

1. Tersane ve Donanma'nın bütün inşaat ve tamir işleri Bahriye Nezareti'nin uhdesinde toplanacak ve bu işler onun tarafından yürütülecektir.

2. Denizcilikle ilgili istisnasız bütün satın alma işleri Nezaret'e bırakılacak ve eskiden bu işlerle uğraşan tüm heyetler Nezaret'in maiyetine gireceklerdir.

3. Bu heyetlerin kullanılması, düzenlenmeleri ve değişikliği Bahriye Nazırı'nın rey ve temyizine birakılacaktır.

4. Mutad ve muayyen masraflardan başka, yeniden gemi inşaası ve büyük çapta harcamalar gerektiren işler Nazır tarafından Bâb-1 âlî'ye bildirilecek, Vükelâ-yı Devlet arasında yapılacak görüşmelerden sonra konu Padişah'a arz olunup irade-i seniyye gereğince hareket edilecektir.

5. Bahriye askerlerinin ve gemilerin sayılarının artırılması gerektiğinde, Kaptanlık Makamı ve Bahriye Nazırı müşterek karar vereceklerdir.

6. Bahriye askerlerinin yiyecek, kıyafet ve maaşları gibi konular Kumanda Meclisi tarafından Kaptanlık Makamı'na bir raporla sunulacak,

\footnotetext{
${ }^{56}$ Bahriye Nezareti'ne bağlı iki ayrı meclisin olușturulması ve bu meclisierin görevleriyle ilgili ayrıntılı bilgi için bkz.; Anabritannica Genel Kültür Ansiklopedisi, C.:IV, İstanbul, 1993, s. 150 .
} 
Kaptanlık Makamı da bu raporu onayladıktan sonra Bahriye Nezareti'ne sunacaktır.

7. Nihayet yeni teşkilâtın ana gayesi, masrafları en alt düzeyde tutarak yapılan işlerin azamî faydayı sağlaması temeline oturtulmuş, Nezaret bu konuda sorumlu tutulmuştur. ${ }^{57}$

Görüldüğü üzere, Bahriye Nezareti’nin kurulmasındaki amaç, Tersane-i Âmire'nin malî işlerinin bir düzene sokulması ve yapılacak harcamaların yerinde olmasina dikkat edilmesidir. Bahriye Nezareti'ne Tersane ve Donanma'nın malî durumunu yürütmekte tam yetki verilmiş, bazı askerî hususlarda ise (özellikle askere alma konularında) Nezaret'in Kaptanlık Makamı ile müşterek hareket etmesi öngörülmüştür. Ancak Kaptanlık Makamı Nezaret'in kuruluşundan bir ay sonra kaldırılınca, Tersane ve Donanma ile ilgili tüm işler Nezaret'e bırakılmıştır.

Nizamnamelerden "Kapudânlık Mesned-i Celîlinin Vezâif-i Esâsiyyesi" başlığını taşıyan ikincisi ise, hem Kaptanlık Makamı'nın, hem de onun maiyetindeki Kumanda Meclisi'nin görevlerini düzenlemiştir. Bu Nizamname'de; Mesned-i Kapudânî'de bulunan zâtın bütün Donanma-yı Hümayun'un baş kumandanı olduğu belirtilmiş, komutanlık mesnedine muavin ve müşavir olmak üzere dört-beş ümera-yı bahriyyeden mürekkep bir meclisin (Kumanda Meclisi) oluşturulması öngörülmüş, Donanma'nın bir ya da daha çok kısmının devletçe lâzım gelen mahallere gönderilmesinin Kaptanlık Makamı ile Kumanda Meclisi'nin marifetiyle olacağı kabul edilmiş ve Donanma'nın ümera ve subaylarının tayin ve nizamları ile ilgili olarak Kumanda Meclisi tarafindan Kapudaniyye'ye arz edilen mazbatalarm Nezaret ile birlikte tasdik olunması ilkesi benimsenmiştir. ${ }^{58}$

Bahriye Nezareti'nin kurulduğu sırada Kapudanlık Makamı'nın maiyetinde olan Kumanda Meclisi, Nezaret ile Kaptanlık Makamı aracılığı ile irtibat halinde iken, Kapudanlık Mesnedi'nin 1867'de çıkan bir irâde ile kaldırılması sonucu doğrudan doğruya Bahriye Nezareti'ne bağlanmıştır. Bu tarihten sonra Kumanda Meclisi'nin hazırladığı mazbataların, tıpkı İdare Meclisi'nin hazırladığı mazbatalarda olduğu gibi Bahriye Meclisi'ne gönderilmesi, orada gözden geçirildikten sonra da Bahriye Nezareti'ne sunulması esası öngörülmüştür. ${ }^{59} 1867$ 'de Kaptanlık Makamı ilga edilince, durum Tersane-i Âmire ile ilişkisi olan İstanbul haricindeki tüm liman ve ilgili mahallere bir genelge ile bildirilmiştir. ${ }^{60}$

Kaptan Paşalığın kaldırılmasından sonraki dönemde Bahriye Nazırı'nın Bahriye Mektebi ile ilgili sorunlan Mekteb-j Bahriye Nazırı aracılığı ile

\footnotetext{
${ }^{57}$ GENCER; a.g.e., s.323 vd.

58 GENCER; a.g.e., s.335 vd.

${ }^{59}$ PARMAKSIZOĞLU; a.g.m., s.210.

"GENCER; a.g.e. s.337.
} 
takip etmesi esası da benimsenmiştir. Mektep Nazırı mektebin ıslahı ile ilgili olarak hazırladığı raporları Bahriye Meclisi'ne havale edecek, Meclis tarafından yapılan görüşme sonucunda bir mazbata hazırlanacak ve bu, Bahriye Nezareti'ne havale edilecekti. ${ }^{61}$

Yeni düzenlemede, Bahriye Nezareti'nin görev ve yetkilerinin önemli ölçüde genişlediğini bu örnekten de anlayabilmek mümkündür. Tanzimat Dönemi'nin reformist özelliği denizcilik alanında da kendisini hissettirmektedir.

Osmanlı devlet teşkilâtında beşyüz seneyi aşkın bir geçmişe sahip olan "Kaptan Paşalık" kurumunun 1867'de kaldırılarak yerine Bahriye Nezareti'nin kurulması bir süre olumlu karşılanmış ve herhangi bir tepki de doğurmamıștır. Ancak 7 Mayıs 1876 (12 Rebiülahır 1293) tarihinde, ikinci defa Bahriye Nazırlığı'na atanan Kayserili Ahmet Paşa tekrar "Kaptan Paşalık" unvanını kullanmaya başlamıştır. Bu dönüşüm, Kayserili Ahmet Paşa'nın Nazır olarak atanmasından sadece 25 gün sonra gerçekleşmiştir. ${ }^{62}$ Bu durumu açıklığa kavuşturan Padişah Fermanı'ndaki ifade ilgi çekicidir:

"Bahriye Nazırı devletlü Ahmet Paşa hazretlerine Kapudân-1 Deryalık unvanı ihsan buyurulmuş olduğundan, iktizâsının icrâsı şeref-sünûh ve südûr buyurulan emir ve ferman...."

Kayserili Ahmet Paşa'nın "Kaptan Paşa" unvanını alması ile ilgili olarak ünlü tarihçi Lütfi Efendi ilginç bir yorum getirmektedir. Tarihçi, okuma yazma bilmediği için Ahmet Paşa'yı son derece "cahil ve basit" bulmakta, onun Kaptan Paşa olarak atanma sebebi olarak da Sultan Aziz Han'ın bu makamı buyurmasını göstermektedir. ${ }^{64}$

Kayserili'nin Kaptan Paşalığı yedi aydan biraz fazla sürmüş, bu şahıs 31 Aralık 1876 (14 Zilhicce 1293)'da II.Abduilhamit tarafından azledilerek ${ }^{65}$ yerine Girit Valisi Mehmet Rauf Paşa - ikinci kez olarak - Bahriye Nazırlı̆ı'na getirilmiştir. Bu kişinin döneminde "Kaptan Paşalık" unvanı tekrar Nazırlığa çevrilmiştir. ${ }^{66}$ Mehmet Rauf Paşa'dan sonra Bahriye Nazırlığı'na getirilen Said Paşa ve Moralı İbrahim Paşa'nın ikinci nazırlıklarını müteakip Nazır olan Hacı Vesim Paşa, Bahriye Nazırlığı'nı tekrar Kaptan Paşalığa dönüştürmüş, kendisinden sonra gelen Hacı Rasim

${ }^{61}$ GENCER; a.g.e., s.339.

${ }^{62}$ PARMAKSIZOĞLU; a.g.m., s.210.

${ }^{63}$ GENCER; a.g.c., s.340.

${ }^{64}$ UZUNÇARŞILI, I. Hakkı; "Sultan Abdülaziz Vak'asına Dair Vak'anüvis Lütfi Efendi'nin Bir Risalesi", Belleten, C.: Vll ${ }^{2}$, S.: 28, Ankara, 1943, s.369

${ }^{65}$ Kayserili Ahmet Paşa'nın Sultan Abdülaziz'i hal'etme yolundaki çabaları ve II Abdülhamid'in bu zâtı Kaptan Paşalık'tan azletmesi ile ilgili ayrıntılı bilgi için bkz.; UZUNÇARŞILI, İ. Hakkı; Kayserili Ahmet Paşa Hakkında II.Abdülhamid'in Bir Hatt-1 Hümayunu", Belleten, C.: VII ${ }^{1}$, S $:: 25,26,27$, Ankara, 1943, s.535 vd.

"UZ UZUNÇARŞILI; Osmanlı Devleti'nin Merkez ve BahriyeTeşkilâtı, s.420. 
Paşa da "Kaptan Paşa" unvanını kullanmıştır. 8 Ocak 1880'de "Bahriye Nazırı" unvanı ile Bahriye'nin başına geçen Bozcaadalı Hüseyin Zade Hasan Paşa zamanında ise yeniden unvan değişikliğine gidilerek nazırlığa dönülmüş ve ondan sonra "Bahriye Nazırı" unvanı devletin sonuna kadar hiç değiştirilmeden muhafaza edilmiştir. ${ }^{67}$

Sözii edilen gelişme çerçevesinde "Kaptan Paşalık" unvanının ara ara yeniden kullanılmış olması 1867 öncesinin Kaptan Paşalığı'nı geri getirmemiştir. Ortada sadece bir unvan değişikliği söz konusudur; zira Kaptan Paşalığın 1867'de kaldırılması ve ardından denizcilik alanında yukarıda belirtilen değişikliklerin gerçekleştirilmesi, artık Tanzimat Dönemi ile birlikte klâsik yapıdan daha farklı esaslara bağlanan yepyeni bir devlet modelinin kabul edildiğinin işaretlerini vermektedir. Tanzimat Dönemi'nin diğer reformlarında olduğu gibi, denizcilik alanında da oldukça ilerici adımlar atılmış ve sistem düzenli bir işlerliğe kavuşturulmuştur. Şu durumda, eski sistemin bir parçası olan Kaptan Paşalık tarihin derinliklerine gömülmüş, eskiden Kaptan Paşa atandığında düzenlenen her türlü merasim ve adet; (örneğin top atılması, paşa gemisine bayrak çekilmesi, paşanın bindiği filikaya önlü-arkalı bayrak asılması gibi) de son bulmuştur. ${ }^{6.8}$

\section{SONUÇ}

Kuruluş döneminden itibaren kısa sürede üç kıtaya birden yayılan Osmanhlar denizciliğe gereken önemi vererek, kurdukları teşkilâtın başına atanmak üzere XVI. yüzyılın ortalarından itibaren "Kaptan Paşalık" kurumunu ihdas etmişlerdir.

Kaptan Paşa, merkez örgütünün en önemli yöneticilerinden biri olarak donanmanın baş komutanlığını yapmış, ayrıca önemli deniz aşırı eyalet ve adaları yönetmek, bahriyeye ait atamaları ve tımar dağıtımlarını yapmak ve donanmanın her an güçlü tutulmasını sağlamakla görevlendirilmiştir. Kaptan Paşa'nın vezir rütbesinde olmak ve İstanbul'da bulunmak koşuluyla Divan-1 Hümayun'un bir doğal üyesi olduğu da unutulmamalıdır. Kaptan Paşa Divan-1 Hümayun'da denizcilikle ilgili konularda açılmış davaları çözüme ulaştırırken, sefer sırasında da görevi ile ilgili konularda hüküm vermiş, Padişah adına tuğralı buyruklar çıkarmış, Siyaseten Katl yetkisini de kullanmıştır.

$\mathrm{Bu}$ derece çeşitli ve önemli görevleri bulunan Kaptan Paşa, Osmanlı devlet örgütünün diğer üst düzey yöneticileri gibi Padişah'ın mutlak yetkilerinin bir bölümünü O'nun adına kullanan bir görevlidir. Kendisi çok sayıda görevini başarıyla yürütebilmek için geniş yetkilerle donatılmış, bir yandan da merkezin sıkı denetimine tabi tutulmuştur. Padişah ve Vezir-i

\footnotetext{
${ }^{67}$ GENCER; a.g.e., s.341.

${ }^{*}$ UZUNÇARŞILI; Osmanlı Devleti'nin Merkez ve Bahriye Teşkilâtı, s.420.
} 
azam'ın sık sık Tersane'yi ziyaret etmeleri, bu ziyaretler sırasında önemli teşrifat kurallarının uygulanması ve Kaptan Paşa'nın Divan-ı Hümayun ile İkindi Divanı'nda yer alması onun Padişah ve Vezir-i azam'ın sürekli denetimi altında tutulduğunu göstermektedir.

Tanzimat Dönemi'nde gerçekleştirilen reform hareketleri sırasında Kaptan Paşalık kaldırılarak yerine Bahriye Nezareti kurulurken, denizcilik alanında başka yeni kurum ve kurallar da Osmanlı devlet örgütüne girmiștir. $\mathrm{Bu}$ yenilikler II.Mahmut döneminde temeli atılmış bulunan Kabine Sistemi'ne işlerlik kazandırmaya yönelik olarak değerlendirilebilir. Böylece XVII. yüzyıldan itibaren Divan-1 Hümayun'un silikleşmesi ve görevinin Vezir-i azam'ın divanı olan İkindi Divanı'na geçmesi ile başlayan süreç, Tanzimat Dönemi'nde bakanlıkların oluşmasıyla tamamlanmış sayılabilir. İște 1867'de Kaptan Paşalığın kaldırılarak yerine Bahriye Nezareti'nin kurulması da bu gelişimin bir parçasıdır.

Şu halde, Kaptan Paşalık sadece Osmanlı devlet örgütünün önemli bir makamı olarak algılanmamalı, ayrıca onun, yapılan değişikliklerle modern devlet sistemine giden yolda bir basamak teşkil ettiği de düşünülmelidir. 


\section{KAYNAKÇA}

1. AFETINAN, A.; Pirî Reis'in Hayatı ve Eserleri, Ankara, 1992.

2. AHISHALI, Recep; Osmanlı Devlet Teskilâtında Reisülküttaplık, İstanbul, 2001.

3. Anabritannica, Genel Kültür Ansiklopedisi, C.:IV, İstanbul, 1993.

4. ANADOL, Cemal - ABBASOVA, Fâzile; Türk Kültür ve Medeniyeti, İstanbul, 2002.

5. AYDIN, M. Akif; Türk Hukuk Tarihi, İstanbul, 1999.

6. CIN, Halil - AKGÜNDÜZ, Ahmet; Türk Hukuk Tarihi C.: I, Konya, 1989.

7. GENCER, Ali İhsan; Bahriyede Yapılan Islahat Hareketleri ve Bahriye Nezaretinin Kurulusu Ankara, 2001.

8. INAN, Abdulkadir; Tarihte ve Bugün Samanizm, Ankara, 1995.

9. MUMCU, Ahmet; Divan-1 Hümayun, Ankara, 1986.

10. MUMCU, Ahmet; Siyaseten Katl Ankara, 1963.

11. PARMAKSIZOĞLU, İsmet; Kaptan Paşa İslâm Ansiklopedisi, C.: VI, İstanbul, 1967, s.206-210.

12. SAKAOĞLU, Necdet; Bu Mülkün Sultanları, İstanbul, 1999.

13. SHAW, S.J.; Between Old and New, Cambridge, 1971.

14. UZUNÇARŞILI, İsmail Hakkı; "Kayserili Ahmet Pasa Hakkında II.Abdiulhamid'in Bir Hatt-1 Hümayunu", Belleten, C.: VII ${ }^{1}$, S.: 25,26,27, Ankara, 1943, s.523-542.

15. UZUNÇARŞILI, İsmail Hakkı; Osmanlı Tarihi, C.:I, Ankara, 1982.

16. UZUNÇARŞILI, İsmail Hakk1; Osmanlı Devleti'nin Merkez ve Bahrive Teskilâtı, Ankara, 1988.

17. UZUNÇARŞILI, İsmail Hakkı; Osmanlı Devleti'nin Saray Teșkilâtı. Ankara, 1988.

18. UZUNÇARŞILI, İsmail Hakkı; "Sultan Abdülaziz Vak'asına Dair Vak'anüvis Lütfi Efendi'nin Bir Risalesi”, Belleten, C.: VII ${ }^{2}$, S.: 28 , Ankara, 1943, s.349-373.

19. ÜÇOK, Coşkun - MUMCU, Ahmet - BOZKURT, Gülnihal; Türk Hukuk Tarihi, Ankara, 1996.

20. YÜCEL, Yaşar - SEVIM, Ali; Klâsik Dönemin Üc Hükümdarı; Fatih -Yavuz-Kanunî. Ankara, 1991.

21. YÜCEL, Yaflar-SEV^M, Ali; Türkiye Tarihi, C.: II, Ankara, 1990. 